\title{
Fisher Folk and the Need for Developing Their System of Education for Sustainable Development: A Survey of Yauri Emirate in Kebbi State
}

\author{
Abu-Ubaida S. ${ }^{1}$, Dahiru L. B..$^{2 a}$, Hassan $S^{2}$. and Bushira Abdullahi ${ }^{3}$ \\ ${ }^{I}$ Department of Educational Foundations Usmanu Danfodiyo University, Sokoto \\ ${ }^{2 a}$ School of Education Aminu Saleh College of Education, Azare ${ }^{2 b}$ Giade L.G.E, Bauchi State \\ ${ }^{3}$ School of Vocational and Technical Education ATAP Bauchi Nigeria
}

\begin{abstract}
The pre-eminent masterminded devotion to ensuring access to, at least, basic education for every citizen, has sought the need to nomadic education in Nigeria. However, this is to take to the doorstep of the nomadic and other disadvantaged groups, education.Perhaps, as directed by the Nigerian National Policy on Education. The nomadic population in Nigeria has been estimated to be about 9.3 million people of whom about 3.1 million are juvenescence school-aged children. The prepotencies of this population are pastoralists, whereby the remaining population consists of fisher folk and farmers. Fisher Folk Education programs are being implemented in some parts of the country considered to have fisher folk communities with larger populations, such as Rivers, Bayelsa, Cross River and Akwa-Ibom states among others. However, none of such educational set-ups is in place in Northern Nigeria, whereas there is the need, as in the case of Yauri Emirate of Kebbi state. This paper therefore addresses the importance of fisher folk education (i.e. improving environmental literacy among others) in Northern Nigeria (precisely Yauri Emirate), their contribution to the nation's economy as well as sustainable national development (i.e. food provision and lessening of unemployment among others). Finally, the work suggests some possible elixirs for the eradication of illiteracy among fisher folk in Yauri Emirate. One of such is government's efforts as to send team of surveyors for an inspection as a step towards exposing Yauri Emirate Fisher folk community to at least basic education.
\end{abstract}

\section{Introduction}

Concentrating on fishing by children of fisher folk, thus abandoning education, is indirectly subjecting them to socio-economical and indeed educational inequality (Yabo, 2009; Umar, \& Illo, 2014). However, they remain victims of discrimination from access to political and other socio-economic benefits. The only remedy to the situation is by providing educational means to their teaming population. Mahuta, (2007) holds that, if education is properly given to them (the minority groups), they will fully be integrated into main stream of the Nigerian society.

There are several factors responsible for the law and or non-participation in education by minority groups, fisher folk specifically. They include poverty, illiteracy and lack of orientation, Nigerian educational nature, lack of concern by government, as well as cultural and religious reasons among others (Mahuta, 2007; Yabo, 2009). Occupational and environmental nature of fisher folk stands a reason for their low educational participation. This is because, as we live with things around our environment, they influence us by sharpening our thinking or dictating our mode of living (Ezewu, 1986). DFID, (1999) observed that people's livelihoods are fundamentally affected by seasonality, over which they have limited or no control. In another perception, almost contrary to this, Eggleson, (1977) holds that, low level of educational participation of fisher folk is not just as a result of their constant migration, but also subject to their economic, political and social characteristics (Eggleson, 1977).

There have been researches on the need of providing educational opportunities to fisher folk education in some specific places in the north. One of such is a Ph. D. Thesis entitled A Suvey of the Educational Needs of the Fishermen in Sokoto State, Nigeria, by Yabo, (2009). However, this paper looks into the factors responsible for law educational participation of fisher folk and the need of providing educational system to them. This is specifically in Yauri Emirate of Kebbi state.

\section{Conceptualization Of Terms}

Fisher folk: Fisher folk are defined as people who fish especially for living (Merriam Dictionary, ND). They sometimes move in search of fish as dictated by the type of fishes required, the movement of the tide and season of the year (Tawari, 2002). 
Yauri Emirate: It is an Emirate in Kebbi state, Nigeria, comprising of three local government areas, namely Yauri, Ngaski and Shanga. It has the population, as of 2012, of 353,808 people (Salamone, 1987; National Population Commission, 2012; Umar, Birni \& Gona, 2012).

\section{Minority Group and the Attempt to Their Educational Provision in Nigeria}

Minority groups, educationally, are those groups of individuals who have little or no access to formal and non-formal education. In such instances, their level of participation in existing educational programs is definitely low in general (Umar, 2000; Yabo, 2009). These minority groups include; the physically challenged, the Bush Kambari, Prison inmates, the nomads and indeed the fisher folk (Dukku, 2000; Umar, 2000; Yabo, 2009).

As strive towards tackling the educational problems of the disadvantaged, programs were launched, to provide educational opportunities to the minority groups. These programs include:

i. Girl Child Education: The launching of girls education project was in the year 2004. Nigerian girls are exposed to accessing formal education by launching of this program. The program was supported by UNICEF and DIFID (Yabo, 2009).

ii. Special Education: This program targets the physically challenged Nigerian. They include handicapped, lame, deaf/dump and blinds. The program is a joint task between the ministry of education and ministry of health, social welfare and labour (Akinpelu, 1994, Yabo, 2009).

iii. Nomadic Education: The nomadic education for pastoral nomads is the handwork of NCNE in collaboration with states and local governments as well as the entire local community. Yabo, (2009) says, by the year 2001, there exist about 1102 schools of nomadic pastoralists across the federation.

\section{Fisher Folk Education in Nigeria}

NCNE in 1988 categorized nomads in Nigeria into nomadic pastoralists and artisanal fishermen (the nomadic fisher folk). The two groups, put together, have the population of about 9.3 million (NCNE; 1988; Yabo, 2009). Out of this population, about 2.8 million are fisher folk. However, reasonable part of this population is of school age children. This is indeed the reason, in an attempt of providing educational opportunity for all, the federal government established the National Commission for Nomadic Education (NCNE). The commission is however up to:

i. Provide the nomads with relevant and functional basic education.

ii. Improve the survival skills of the nomads by providing them with knowledge and skills that will enable them raise their productivity and levels of income.

iii. Participate, effectively in the nation socio-economic and political affairs (Yabo, 2009)

During the previous years, the attention of NCNE was basically on the nomadic pastoralist, until the year 1990. In 1990, NCNE approved a national program aimed at educating the children of fisher folk. However, this program concentrated heavily in the southern part of the country; perhaps in states thus, Rivers state (which is the pioneer), Bayelsa, Cross River, Akwa-Ibom, Anambara, Delta, Edo, Ondo and Ogun states. The NCNE report made in 2006 shows that, about 40,842 childrens of fisher folk are beneficiaries of the program by the year 2001 (Yabo, 2009). The National Council Education promulgated the educational program of fisher folk in the year 1990. It was then that council approved this programme in nine Nigerian states (Rivers, Bayelsa, Cross Rivers, Akwa-Ibom, Anambara, Delta, Edo, Ondo and Ogun states) (Ezuwu and Tahir in Yabo, 2009).

However, it could be observed here that, educational provision for children of fisher folk have been available only in the southern part of the country.

\section{Yauri Emirate and Fishing Activities}

Yauri is an emirate in Kebbi State, Nigeria. It is located in the North- West corner of Sokoto State. The Emirate comprises three local government areas, namely; Yauri (with headquarters at Yelwa), Ngaski (with headquarters at Wara) and Shanga (with headquarters at Shanga). The area falls within about $80 \%$ of the total area of the Kainji lake. It is located on latitudes $11^{0} 15^{1}-12^{0} 30^{1} \mathrm{~N}$ and longitudes $5^{0} 18^{1}-11^{0} 20^{1} \mathrm{E}$. Its minimum temperature is $32^{\circ} \mathrm{C}$, which occurs in December (during harmattan). However, the highest mean daily temperature of $39^{\circ} \mathrm{C}$ occurs in March and April (Yauri Meteorological Station, in Umar, Birni \& Gona, 2012). The Kambari were the first group of people to sit in the area (called Yauri today), since before $13^{\text {th }}$ centuries (Adamu, 1968; Balogun, 1970; Salamone, 1987). Today, Yauri is one of the smallest historical emirates in Northern Nigeria. In 1972, the population was about 112,000 people inhabiting a land area of about 1,306 square miles $\left(3,380 \mathrm{~km}^{2}\right)$ and scattered over six major districts (Salamone, 1987). However, by the year 2012 , the emirate has a population of 353,808 people. Out of this figure 100,564 reside within Yauri local Government LGA, while 127,142 and 126,102 were found in Shanga and Ngaski LGA respectively (National Population Commission, 2012; Umar, Birni \& Gona, 2012).

Yauri Emirate has been productive in farming and fishing since its early years. Up to today, Yauri serves as an important marketing center for smoked fish in the country (Adamu, 1968; Bologun, 1970; Salamone; 1987; Umar \& Illo, 2014; Labaran, S. 2016). This is to say, fishermen in Yauri have been 
economically contributive. Perhaps, fishing plays a vital role in Nigerian economy. It has been a source of income to many citizens, thus, reduces the problem of unemployment and provides a source of food (Tawari, 2002; Umar \& Illo, 2014).

\section{Importance of Educating Fisher Folk}

The importance of education, generally, could not be overemphasized. As part of Nigerian community, fisher folk in Yauri emirate need to be educated. Generally, Yabo, (2009) considered the following as the anticipated positive effects of educating fisher folk:

i. It will equip them with skills of managing fish farm, which entails breeding, harvesting and marketing of fish products and the use of banking services.

ii. They would be provided with the knowledge of adequately adopting of modern technologies in the development of fish farms, fish processing and privation.

iii. Educating fisher folk is also useful in acquisition of knowledge of the prevention and control of hazards in fishing ecology.

iv. Education would orient them on knowledge of their legal rights and privileges as Nigerian citizens.

v. Education would provide them with the knowledge of how to maintain a health family.

It should be understood at this juncture that, when these strategies are carefully pursued, migrant fishing communities in Nigeria will obtain the necessary pre-requisite for modern life and get involved in all educational programs actively (Yabo, 2009).

\section{Reasons of Migrants Fisher Folk Reluctance to Education}

Yabo, (2009) interviewed fishermen in nine villages of Sokoto (Rimawa, Gidan Gijire, Muza, Kambama, Gidan Hussaini, Gidan Rakkel, and Gidan Gangan). He found that, the following are responsible for the non-participation of the fisher folk children educationally:

i. High poverty level among parents

ii. Lack of job opportunities after completing school

iii. Poor quality of teaching

iv. Lack of infrastructural facilities

v. Lack of job after completing school

vi. Migrating nature of fisher folk (Yabo, 2009)

However, NCNE, (1988) outline some problems faced by educational provision for fisher folk thus:

i. Low level of enrolment

ii. Drop-out rate

iii. Inadequate teachers

iv. Inadequate instructional materials and infrastructures

v. Funding (NCNE, 1988)

\section{Requirements for Educational Provision to Fisher Folk in Yauri Emirate}

Specifically, the following are areas at which the Yauri fisher folk need to be educated:

i. Religious education: Religion is almost inseparable from human life. It guides the total way of human affairs. Having adequate religious knowledge guides individual towards being lawful and truth worthy. It also tackles the problem of religious extremism. Religious education risks undermining the place of this core subject in all schools, just at a moment when deeper reflection on religion, belief, spirituality and ethics could contribute enormously to the emergence of a society that seeks to embrace difference and is comfortable to celebrate the presence of a variety of religious and other belief systems (Gareth, 2014).

ii. Literacy and numeracy skills: Getting literacy and numeracy education would help fishermen manipulate best, their occupation of fishing. Thus, they would make rational utilization of materials available for the maximization of productivity in their fishing activities.

iii. Political awareness: Role of youth in present day politics' stressed the need for political awareness among the youth (Ravi, 2013). Political stability and development of any political system is a function of the awareness and positive involvement of the citizens in civic and political matters. Political awareness is a remedy to political violence which has become synonymous with Nigeria's political culture such that virtually all elections held so far in the country are violent-ridden (Ojo, 2014; Palade, 2014). Therefore, children of fisher folk in Yauri need political education.

iv. Agricultural education: Agriculture plays a crucial role in the life of an economy. It is the backbone of our economic system. Agriculture not only provides food and raw material but also employment opportunities to a very large proportion of population. Thus, education is needed on how this sector could be efficiently utilized (Karuna, 2012).

\section{Conclusion}

The federal government has made many attempts to provide educational opportunities to the minority groups. This is however by launching programs mainly for catering the educational needs of such groups. The programs launched by federal government in this regard include; Girl Child Education, Special Education and 
indeed Nomadic Education. Educational opportunities are also provided to children of fisher folk in some Nigerian states, especially in the sourthern part of the country. These states are; Rivers, Bayelsa, Cross Rivers, Akwa-Ibom, Anambara, Delta, Edo, Ondo and Ogun states. Research works have shown that there is the need of such educational programs in some specific areas in the north. One of such areas is Yauri Emirate in Kebbi state.

\section{Suggestions}

1. Government should make an effort as to send team of surveyors for an audit as a step towards exposing Yauri Emirate Fisher folk community to at least basic education.

2. The data gathered by the team of surveyors should be analyzed respectively and subsequent steps should be taken accordingly.

3. The needs of the community should greatly and adequately taken into consideration. Thus, the educational provision should emphasize on Agricultural education, political awareness, literacy and numeracy skills and indeed religious knowledge.

\section{References}

[1]. Adamu, M. (1968). A Hausa government in decline: Yauri in the nineteenth century. M. A. dissertation, Ahmadu Bello Univerity, Zaria.

[2]. Akinpelu, J. A. (1994). Education for groups. In Akinkugbe, O. O. (eds). Nigeria and Education: The Challenges Ahead. Ibadan: Spectrum Books Ltd.

[3]. Balogun, S. A. (1970). Gwandu Emirates in the nineteenth century with special reference to plitical relations 1817-1903. M. A. dissertation, University of Ibadan.

[4]. Department for International Development (DFID) (1999). Sustainable livelihood guidance. Retrieved from: www.livelihoods. org/info/info.guidancesheet

[5]. Dukku, M. G. (2000). A general biew on the contribution of universities in the education of the disadvantaged groups in Nigeria. A paper presented at the Natioal Conference on Education of Disadvantaged, held at FCE Yola.

[6]. Eggleston, J. (1977). The ecology of the school. In Tahir, (ed) Ecology and Education in Nigeria. Onisha: Tabans Publishers Limited.

[7]. Ezewu, E. E. (1986). Ecology and education in Nigeria. In Tahir, (ed) Ecology and Education in Nigeria. Onisha: Tabans Publishers Limited.

[8]. Gareth, B. (2014). Why religius education has an important role to play in our society. http://www.irishtimes. com/news/education/ why-religious-education-has-an-important-role-to-play-in-our-society-1.1853105

[9]. Karuna, (2012). What is the importance of Agriculture for our country? retrieved from: http://www.preservearticles com/201107169225/what-is-the-importance-of-agriculture-for-our-country.html

[10]. Labaran, S. (2016). Sana'ar sassakar jirgin ruwa a garin Yauri. B. A. project, Department of Nigerian Languages, Usmanu Danfodiyo University, Sokoto.

[11]. Mahuta, G. A. (2007). An assessemnt of the need of Bush Kambari and their children in Kebbi State, Nigeria. Unpublished Ph. D. thesis, Usmanu Danfodiyo University, Sokoto.

[12]. Merriam Dictionary, (ND). Definition of fisher folk. Retrieved from: http://www.merriam-webster.com/dictionary/fisherfolk

[13]. National Commission for Nomadic Education (NCNE), (1988). Situation Report on nomadic education. Retrieved from; www1.chr.up.ac.za

[14]. National Population Commission, (2012). States population in Nigeria. Retrieved from http://www. population. gov. ng/index.php/contactus

[15]. Ojo, O. M. (2014). Electoral security and democratic consolidation in Nigeria. In Ikuejube, G \& Olupayimo, D. Z. (eds) Nigeria's Internal Security Challenges: Strategies for Sustainable Development. Ibadan: John Archers.

[16]. Palade, D. A. (2014). Political participation in Nigerian democracy: A study of some selected local government areas in Ondo state, Nigeria. Global Journal of Human-Social Science: Political Science Volume 14. U.S.A.: Global Journals Inc.

[17]. Ravi, R. (2013). "Youth needs political awareness." Retrived from: http://www.thehindu.com/todays-paper/tp-national/tpandhrapradesh/youth-needs-political-awareness/article3549801.ece

[18]. Salamone, F. A. (1987). Gods and goods in Africa: persistence and change in ethnic and religious identity in Yauri Emirate, NorthWestern State, Nigeria

[19]. Tawari, F. (2002). Dissemination of research findings on nomadic education in Nigeria (The fishermen education experience: Issues and directions. A paper presented at the International Conference organized by International Extension College (IEC) Cambridge, Sponsored by The Department For International Development (DFID) at Rock View Hotel Abuja.

[20]. Umar S., Birnin-Yauri, H. B. \& Gona, A. (2014). Profitability of resettled farmers' crop production enterprise in Yauri Emirate, Kebbi State Nigeria in IOSR Journal Of Humanities And Social Science (IOSR-JHSS), e-ISSN: 2279-0837, p-ISSN: 2279-0845.

[21]. Umar, A. (2000). Educating disadvantaged groups: The Nigerian experience. A paper presented at the Natioal Conference on Education of Disadvantaged, held at FCE Yola.

[22]. Umar, S. \& Illo, A.I. (2014). Performance assessment of artisanal fisheries in the Kainji Dam area of Yauri Emirate, Kebbi State, Nigeria. In Journal of Biology, Agriculture and Healthcare Vol.4, No.20, ISSN 2225-093X

[23]. Yabo, I. M. (2009). A suvey of the educational needs of the fishermen in Sokoto State, Nigeria. Ph. D. Thesis, Usmanu Danfodiyo University, Sokoto. 